\title{
Chromium Speciation in Contaminated Water Samples Using PTFE Beads Packed Minicolumn and FI-FAAS Determination
}

\author{
Shelja Tiwari, Niharika Sharma, and Reena Saxena* \\ Department of Chemistry, Kirori Mal College, University of Delhi, Delhi $-\mathbf{1 1 0 0 0 7}$, India
}

\section{INTRODUCTION}

Metal pollutants are non-biodegradable in nature. Thus, once they enter the environment, the toxicity caused by them mainly depends on the chemical form they exist in. Chromium is one of the common pollutants introduced into water sources as a result of various industrial processes.

The toxicity of chromium depends on its oxidation state. $\mathrm{Cr}$ (III) is considered biologically essential to mammals as it is responsible for the glucose, lipid and protein metabolism. Cr(VI) ions are highly toxic because of their high oxidation potential and small size which allows them to penetrate through cell membranes and thus leads to the oxidation of bio-molecules (1). The toxic effects of $\mathrm{Cr}(\mathrm{VI})$ are chronic ulcers, dermatitis, lung and skin cancers. The World Health Organization (WHO) has decided the permissible limit for chromium in water to be 0.05 $\mathrm{mg} \mathrm{L}^{-1}(2)$.

The development in the industrial sector has amplified the problems associated with environmental pollution. Therefore, remediation of chromium species from industrial effluents has become extremely important. It is due to these two distinct effects that the precise and accurate determination of $\mathrm{Cr}$ (III) and $\mathrm{Cr}(\mathrm{VI})$, especially at ultra-trace levels, in environmental samples is urgently required.

Speciation is defined as the determination of the individual con-

\footnotetext{
*Corresponding author.

E-mail: reenasaxena@kmcollege.ac.in, reenasax@botmail.com

Tel: +9810241580
}

\begin{abstract}
A spectroanalytical method for remediation of chromium species from contaminated water samples based on flow injection hyphenated to a flame atomic absorption spectrometer is proposed. Iminodiacetic acid (IDA) was used as the chelating agent, and the chromium-IDA complex was preconcentrated on the minicolumn filled with polytetrafluoroethylene (PTFE) beads. The chemical and flow variables were optimized. The effect of commonly occurring matrix ions on the recovery of the chromium species was also studied. For a preconcentration time of $120 \mathrm{~s}$, preconcentration factors and detection limits achieved for $\mathrm{Cr}(\mathrm{III}) / \mathrm{Cr}(\mathrm{VI})$ were $68 / 59$, $0.11 / 0.13 \mu \mathrm{g} \mathrm{L}^{-1}$, respectively. The relative standard deviation for 5 replicates of measurements for $100 \mu \mathrm{g} \mathrm{L}^{-1}$ level was $1.2 / 1.4 \%$ for $\mathrm{Cr}(\mathrm{III}) / \mathrm{Cr}(\mathrm{VI})$, respectively. Real water samples collected from industrial sites and the Yamuna river were analyzed and spike recovery tests were performed. The method validation was done by analyzing the chromium concentration in NIST SRM 1640a Trace Elements in Natural Water.
\end{abstract}

centrations of the various chemical forms of an element that together make up the total concentration of that element in a given matrix (3). Spectrometric techniques are most commonly used for trace $\mathrm{Cr}$ determination (4). Flame atomic absorption spectrometry (FAAS) is a popular technique with considerable accuracy and precision. However, in practice for complex matrices, quantification is often very difficult due to the presence of interfering effects, comprised of spectroscopic and non-spectroscopic interferences. Moreover, in some cases, the concentration of the analyte might be too low to be directly analyzed.

The most effective way to avoid these problems is to perform appropriate sample pretreatment aimed at improving the limits of detection (LODs) by removal of interferences as well as preconcentration of the analyte into a smaller sample volume, thus effectively increasing its concentration (5). In order to bring the analyte concentration into the detection range of the detector, a preconcentration step is required before the final measurement. Solid phase extraction (SPE) is an efficient separationpreconcentration technique for trace metal analysis (6) SPE offers the advantages of flexibility, is economical and, more importantly, is environmentally friendly. Despite these advantages, SPE can be timeconsuming, requires large sample or reagent volume, and the risk of contamination and loss of analyte during analysis is common (7).

The combination of flow injection preconcentration using SPE with FAAS determination in an online method (FI-SPE-FAAS) has proven to be an effective system for trace element determination in various systems. It provides better sensitivity, effective removal of interfering ions, low cost, and offers high sampling rate (8). The various on-line systems proposed for the determination of chromium include polymeric support (9), alumina (10), biosorbents (11), and nanomaterials (12). In recent years, polymer-based systems have gained considerable attention in speciation 
analysis because of the advantages of hydro-phobic character, ease of surface modification, thermal stability, and high surface area (13-15).

In the present study, polytetrafluoroethylene (PTFE) beads have been used as the solid phase extractant for the preconcentration of chromium species. PTFE beads possesses properties such as swelling and chemical inertness, low friction coefficient, etc., which makes them appropriate for solid phase extraction studies $(16,17)$. Iminodiacetic acid (IDA) was used as a chelating agent to complex both $\mathrm{Cr}$ (III) and $\mathrm{Cr}(\mathrm{VI})$ at a different $\mathrm{pH}$. Studies have reported that IDA can be used as a complexing agent for both Cr(III) and Cr(VI) $(18,19)$. The optimized method was applied for chromium determination in industrial and river water samples, and spike recovery tests were carried out. The method was validated by analyzing standard reference material (SRM) NIST 1640a Trace Elements in Natural Water (National Institute of Science and Technolgy, Gaithersburg, MD, USA).

\section{EXPERIMENTAL}

\section{Instrumentation}

Chromium determination was performed using the AAnalyst ${ }^{\mathrm{TM}} 400$ flame atomic absorption spectrometer (FAAS) (PerkinElmer, Inc. Shelton, CT, USA), equipped with an air-acetylene burner and deuterium background correction. The on-line preconcentration studies were performed by coupling the FIAS 400 flow injection system (PerkinElmer, Inc., USA) fitted with a glass minicolumn of $3 \mathrm{~cm} x 3 \mathrm{~mm}$ (length $\mathrm{x}$ i.d.) to the FAAS system. The online system was controlled by a personal computer using Winlab32 ${ }^{\mathrm{TM}}$ (version 6.5.0.0266, PerkinElmer, Inc., USA) application software. Tygon $^{\circledR}$ and PTFE materials were used for all tubing and connection purposes. All $\mathrm{pH}$ adjustments were carried out with $\mathrm{pH}$ meter Model
LI-614 (ELICO, India). Ultrapure water (Merck Millipore Corporation, USA resistivity $18.2 \mathrm{M} \Omega \cdot \mathrm{cm}$ ) for all studies was obtained from Milli-Q ${ }^{\circledR}$ water purification system.

\section{Reagents and Standard Solutions}

The chemicals used were of analytical reagent grade. All working standard solutions were prepared daily by dilution from $1000 \mathrm{mg} \mathrm{L}^{-1}$ Cr(III) and Cr(VI) standard solutions (TraceCERT ${ }^{\circledR}$, Sigma-Aldrich, USA) using ultrapure water. PTFE beads (Sigma-Aldrich) and Iminodiacetic acid (Thomas Baker) were used as the solid support and chelating agent, respectively. The $\mathrm{pH}$ of the solutions was maintained using $0.5 \mathrm{~mol} \mathrm{~L}^{-1} \mathrm{HCl}$, phosphate buffer (pH 6-8), and trisodium phosphate buffer (pH 12).

\section{Column Packing}

The PTFE beads suspended in water were packed into the glass mini-column by injecting them with a syringe. The ends of the columns were sealed with cotton. Prior to use, the PTFE bead-packed glass mini-column was rinsed with 2.0 mol L-1 $\mathrm{HNO}_{3}$, then with ultrapure water.

\section{Flow Injection Preconcentration Procedure for Chromium Determination}

The on-line preconcentration of the chromium species using the FISPE-FAAS system is controlled by a computer program which involves separate steps for filling, preconcentration and elution as given in Table I (20). The coupling is an efficient and easy procedure as both systems operate in continuous mode. The sample introduction capillary of the FAAS is connected to the output capillary of the FI system. Thus, the FI preconcentration with FAAS detection improves the nebulization efficiency of FAAS since the flow rate of the reagents can be optimized by flow injection. The first step enables filling of both sample and eluent carrier tubes with their respective solutions. This step is followed by the preconcentration step in which the sample solution is preconcentrated on the mini-column containing the PTFE beads as shown in Figure 1. In the last step, elution of the retained species with the appropriate eluting agent takes place. The eluent containing the desorbed chromium species is directly sent to the nebulizer of the FAAS system for its detection (21). Peak height of the analytical signal is taken as the absorbance. Prior to all measurements, blank measurements were recorded and saved. Triplicate sets of all readings were taken for all solutions.

\section{Real Water Analysis}

The water samples were collected from industrial areas (Anand Parbat, Seelampur and Wazirpur) and the Yamuna River. The water samples were acidified and stored in cleaned polypropy-

TABLE I

Flow Injection Program for Preconcentration of Cr(III) and Cr(VI) Ions Using PTFE Minicolumn and IDA as Complexing Agent

\begin{tabular}{lccccc}
\hline Step & Time (s) & Pump 1 & Pump 2 & Valve Position & Reading \\
\hline Prefill & 1 & + & + & Elute & - \\
1 & 10 & + & - & Load & - \\
2 & 20 & - & + & Elute & - \\
3 & 50 & + & - & Load & - \\
4 & 10 & + & + & Load & - \\
5 & 30 & - & + & Elute & + \\
\hline
\end{tabular}


lene bottles below $4^{\circ} \mathrm{C}$. Before analysis, all solutions were filtered with $0.45 \mu \mathrm{m}$ pore size filter paper (Merck Millipore Corporation) in order to remove suspended particulate matter if present. The water samples were then analyzed for $\mathrm{Cr}$ (III) and Cr(VI) according to the optimized preconcentration procedure, and spike recovery tests with standard Cr(III) and Cr(VI) solutions (TraceCERT $^{\circledR}$ ) were performed.

\section{RESULTS AND DISCUSSION}

\section{Optimization of Chemical and Flow Variables for Preconcen- tration of $\mathrm{Cr}$ (III) and $\mathrm{Cr}$ (VI)}

To ensure maximum recovery of the chromium species using the preconcentration system, the influence of both the chemical (effect of sample acidity, concentration of eluting and chelating agent) and flow variables (effect of sample and eluent flow rates) were studied.

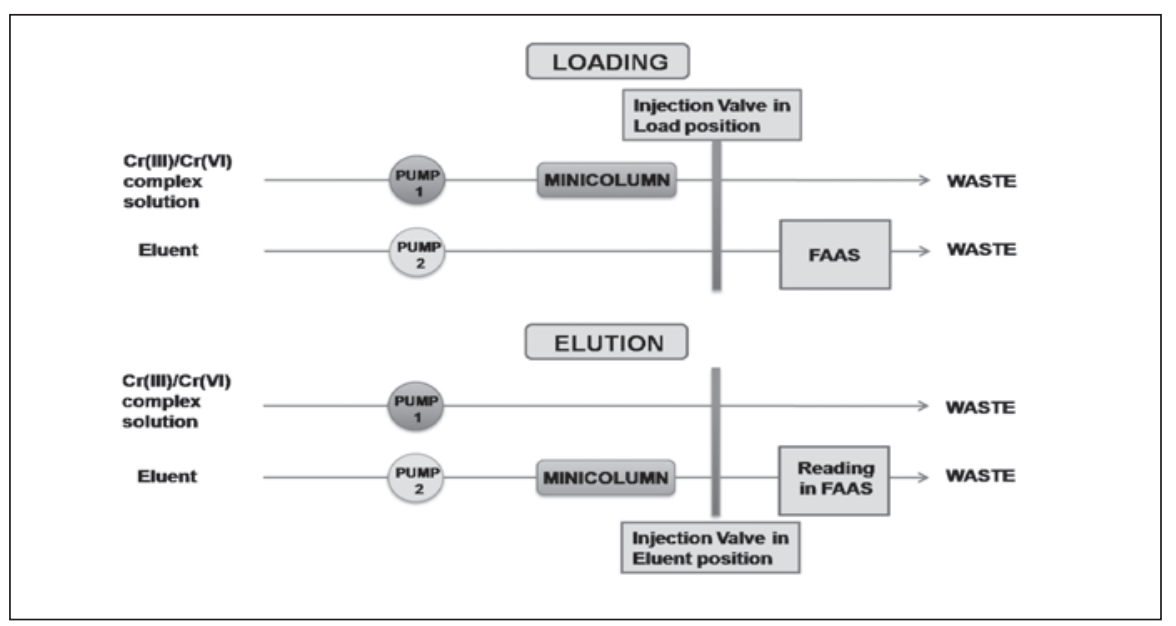

Fig. 1. On-line preconcentration system incorporated with PTFE filled minicolumn for sorption of $\mathrm{Cr}(\mathrm{III}) / \mathrm{Cr}$ (VI) complex.

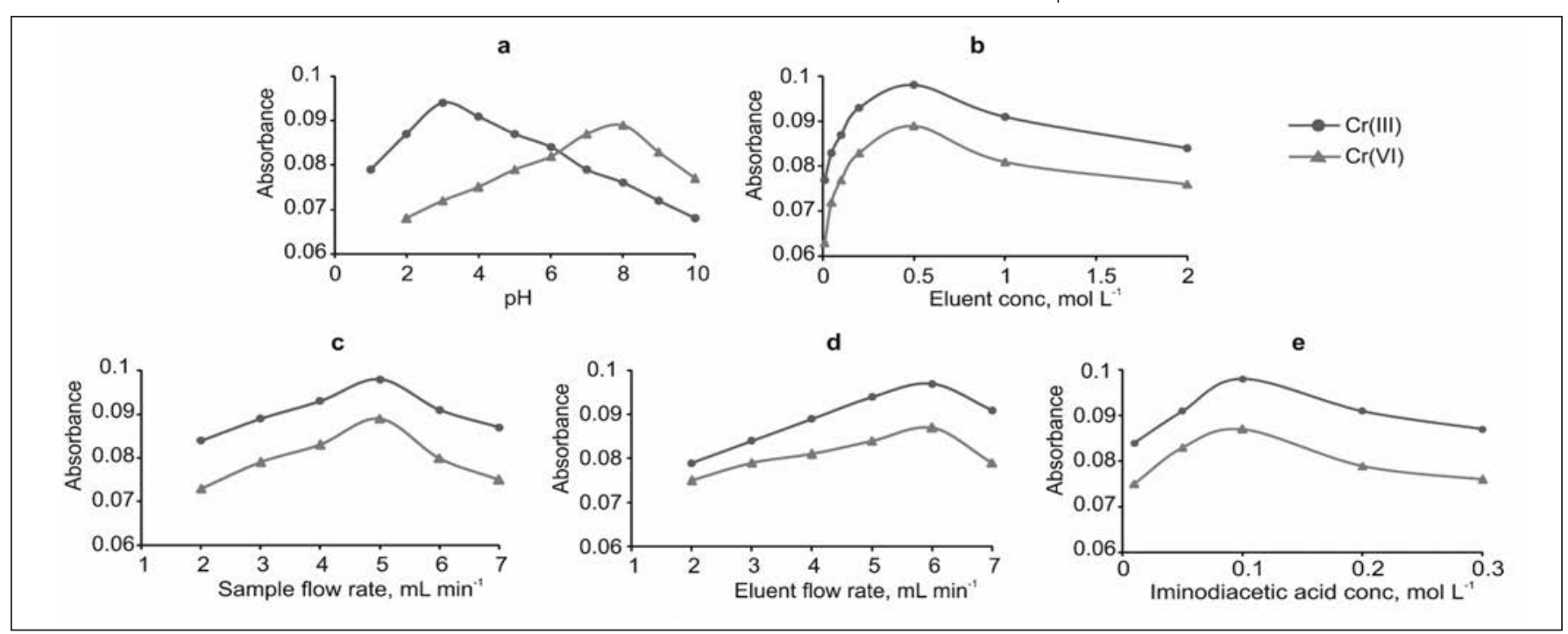

Fig. 2. Optimization of preconcentration procedure of Cr(III) and Cr(VI) using PTFE minicolumn and IDA as complexing agent. (a) influence of $\mathrm{pH}$, (b) influence of eluent concentration, (c) influence of sample flow rate, (d) influence of eluent flow rate, and (e) influence of chelating agent concentration. 


\section{Effect of Chelating Agent}

Sample solutions of iminodiacetic acid solution containing $50 \mu \mathrm{g} \mathrm{L}^{-1}$ each of $\mathrm{Cr}(\mathrm{III})$ and $\mathrm{Cr}(\mathrm{VI})$ were prepared in the concentration range of $0.01-0.3 \mathrm{~mol} \mathrm{~L}^{-1}$. It was observed that maximum absorbance was obtained with $0.1 \mathrm{~mol} \mathrm{~L}^{-1}$ iminodiacetic acid solution (Figure 2e). Thus, for all studies, the Cr(III) and Cr(VI) solutions were prepared in $0.1 \mathrm{~mol} \mathrm{~L}^{-1}$ iminodiacetic acid solution.

\section{Effect of Eluent and Sample Flow Rates}

The contact time between sample/eluent and solid phase extractant is directly related to sample and eluent flow rate. Sample and eluent flow rate studies were done in the range of $2-7 \mathrm{~mL} \mathrm{~min}^{-1}$. The results showed that the sample and eluent flow rates of $5 \mathrm{~mL} \mathrm{~min} \mathrm{~m}^{-1}$ and $6 \mathrm{~mL} \mathrm{m^{-1 }}$ gave maximum absorbance for both Cr(III) and $\mathrm{Cr}(\mathrm{VI})$ species (Figures 2c and 2d).

TABLE II

Effect of Interfering Ions on Recovery of Cr(III) and Cr(VI)

\begin{tabular}{lrc}
\hline $\begin{array}{l}\text { Interfering } \\
\text { Ion }\end{array}$ & $\begin{array}{r}\text { Tolerance Limit }\left(\mathrm{mg} \mathrm{L}^{-1}\right) \\
\mathrm{Cr}(\mathrm{III})\end{array}$ & $\mathrm{Cr}(\mathrm{VI})$ \\
\hline $\mathrm{NO}_{3}{ }^{-}$ & 2100 & 1600 \\
$\mathrm{Na}^{+}$ & 1100 & 850 \\
$\mathrm{Br}^{-}$ & 900 & 750 \\
$\mathrm{Cl}^{-}$ & 900 & 700 \\
$\mathrm{SO}_{4}^{2-}$ & 910 & 990 \\
$\mathrm{I}^{-}$ & 700 & 850 \\
$\mathrm{~K}^{+}$ & 700 & 710 \\
$\mathrm{NH}_{4}^{+}$ & 530 & 580 \\
$\mathrm{Ca}^{2+}$ & 275 & 300 \\
$\mathrm{CH}_{3} \mathrm{COO}$ & 260 & 250 \\
$\mathrm{Zn}^{2+}$ & 8 & 4 \\
$\mathrm{Al}^{3+}$ & 8 & 3 \\
$\mathrm{Cd}^{2+}$ & 3 & 2 \\
$\mathrm{~Pb}^{2+}$ & 1 & 0.5 \\
$\mathrm{Cu}^{2+}$ & 1.0 & 0.5 \\
$\mathrm{Mg}^{2+}$ & 0.5 & 0.5 \\
\hline
\end{tabular}

\section{Effect of Interfering Ions}

Nitrates, chlorides, sulphates, etc., are some of the most commonly found ions in environmental water samples. If present, these ions can interfere in the preconcentration procedure of chromium species. Thus, the effect of the presence of these ions towards the preconcentration of chromium species according to the optimized system was studied. An ion is considered to be interfering if it deviates the analytical signal by more than $\pm 5 \%$. Table II lists the tolerance limits of different interfering ions towards $\mathrm{Cr}(\mathrm{III})$ and $\mathrm{Cr}(\mathrm{VI})$ preconcentration.

\section{Analytical Performance of On- Line Preconcentration System}

The analytical performance of the proposed method under optimum conditions was studied and the results are given in Table III. The preconcentration factor was calculated as the ratio of the calibration curve obtained with and without preconcentration. The precision of the method was studied by calculating the relative standard deviation of five replicates of the measurements of 50 and $100 \mu \mathrm{g} \mathrm{L}^{-1}$ $\mathrm{Cr}(\mathrm{III})$ and $\mathrm{Cr}(\mathrm{VI})$ solutions. For seven blank replicates, the limit of detection and limit of quantification were calculated according to the $3 \sigma$ and $10 \sigma$ criteria, respectively.

\section{Analysis of Real Water Samples and Method Validation}

The proposed method under optimized conditions was applied to real water samples (industrial water and Yamuna river water) for the determination of the $\mathrm{Cr}$ (III) and $\mathrm{Cr}(\mathrm{VI})$ species. Spike recovery tests were also performed and recoveries greater than $95 \%$ were observed for both species. The results are given in Table IV. Method validation was performed by analyzing NIST SRM 1640a Trace Elements in Natural Water. The observed results (40.12 $\pm 1.50 \mu \mathrm{g} \mathrm{L}^{-1}$ ) were in good agreement with the certified values $\left(40.54 \pm 0.30 \mu \mathrm{g} \mathrm{L}^{-1}\right)$ and recovery of $98.9 \%$ was achieved.
TABLE III

Analytical Figures of Merit for Cr(III) and Cr(VI) Preconcentration

\begin{tabular}{|c|c|c|c|c|}
\hline \multirow[t]{2}{*}{ Parameters } & \multicolumn{3}{|c|}{ Figures of Merit } & \\
\hline & \multicolumn{2}{|c|}{$\mathrm{Cr}(\mathrm{III})$} & \multicolumn{2}{|c|}{$\mathrm{Cr}(\mathrm{VI})$} \\
\hline Preconcentration Time (s) & 60 & 120 & 60 & 120 \\
\hline Sample Consumption (mL) & 5 & 10 & 5 & 10 \\
\hline Linear Range $\left(\mu \mathrm{g} \mathrm{L}^{-1}\right)$ & $0.80-120$ & $1.11-110$ & $0.93-100$ & $1.3-90$ \\
\hline Limit of Detection $\left(\mu \mathrm{g} \mathrm{L}^{-1}\right)$ & 0.24 & 0.11 & 0.28 & 0.13 \\
\hline Limit of Quantification ( $\mu \mathrm{g} I$ & $\left.\mathrm{~L}^{-1}\right) 0.80$ & 1.1 & 0.93 & 0.43 \\
\hline Sample Throughput (h) & 30 & 20 & 30 & 20 \\
\hline Preconcentration Factor & 33 & 68 & 28 & 59 \\
\hline Correlation Coefficient & 0.9992 & 0.9996 & 0.9998 & 0.9997 \\
\hline $\begin{array}{l}\text { Regression Equation } \\
\left.\text { (6 standards, Cr(III)/mg L }{ }^{-1}\right) \\
\text { (with preconcentration) }\end{array}$ & $\begin{array}{l}\mathrm{A}_{60}=2.29[\mathrm{Cr}(\mathrm{III})] \\
-0.00212\end{array}$ & $\begin{aligned} \mathrm{A}_{120}= & 4.74[\mathrm{Cr}(\mathrm{III})] \\
& -0.00579\end{aligned}$ & $\begin{aligned} \mathrm{A}_{60} & =1.95[\mathrm{Cr}(\mathrm{VI})] \\
& -0.00116\end{aligned}$ & $\begin{aligned} \mathrm{A}_{120} & =4.13[\mathrm{Cr}(\mathrm{VI})] \\
& -0.00628\end{aligned}$ \\
\hline $\begin{array}{l}\text { Regression Equation } \\
\text { (6 standards, } \mathrm{Cr}(\mathrm{III}) / \mathrm{mg} \mathrm{L}^{-1} \text { ) } \\
\text { (without preconcentration) }\end{array}$ & $\mathrm{A}=0.07[\mathrm{Cr}(\mathrm{III})]-\mathrm{C}$ & 0.00023 & $\mathrm{~A}=0.07[\mathrm{Cr}(\mathrm{VI})$ & +0.00025 \\
\hline Precision (\% R.S.D.) & $\begin{array}{l}1.5,[\mathrm{Cr}(\mathrm{IIII}) \\
1.2,[\mathrm{Cr}(\mathrm{III})\end{array}$ & $\begin{array}{l}]=50 \mu \mathrm{g} \mathrm{L}^{-1} \\
]=100 \mu \mathrm{g} \mathrm{L}^{-1}\end{array}$ & $\begin{array}{l}1.8,[\mathrm{Cr}(\mathrm{VI})] \\
1.4,[\mathrm{Cr}(\mathrm{VI})]\end{array}$ & $\begin{array}{l}=50 \mu \mathrm{g} \mathrm{L}^{-1} \\
=100 \mu \mathrm{g} \mathrm{L}^{-1}\end{array}$ \\
\hline
\end{tabular}




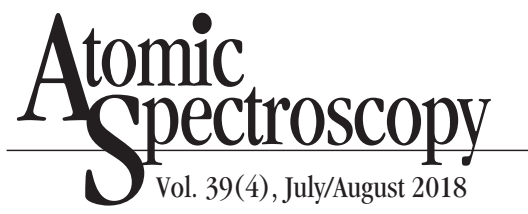

TABLE IV

Analysis of Industrial Water and Yamuna River Water Samples

\begin{tabular}{|c|c|c|c|c|c|c|c|}
\hline \multirow[t]{2}{*}{ Sample } & \multicolumn{2}{|c|}{ Added $\left(\mu \mathrm{g} \mathrm{L}^{-1}\right)^{\mathrm{a}}$} & \multicolumn{2}{|c|}{ Found $\left(\mu \mathrm{g} \mathrm{L}^{-1}\right)^{\mathrm{b}}$} & \multirow[b]{2}{*}{ Total Cr } & \multicolumn{2}{|c|}{ Recovery (\%) } \\
\hline & $\mathrm{Cr}(\mathrm{III})$ & $\mathrm{Cr}(\mathrm{VI})$ & $\mathrm{Cr}(\mathrm{III})$ & $\mathrm{Cr}(\mathrm{VI})$ & & $\mathrm{Cr}(\mathrm{III})$ & $\mathrm{Cr}(\mathrm{VI})$ \\
\hline \multicolumn{8}{|c|}{ Anand Parbat Industrial Area, } \\
\hline Delhi, India & 20 & 20 & $46.4 \pm 3.07$ & $30.8 \pm 0.66$ & & & \\
\hline \multicolumn{8}{|c|}{ Seelampur Industrial Area, } \\
\hline Delhi, India & 20 & 20 & $42.0 \pm 3.22$ & $26.6 \pm 2.47$ & & & \\
\hline \multicolumn{8}{|c|}{ Wazirpur Industrial Area, } \\
\hline Delhi, India & 20 & 20 & $51.1 . \pm 1.56$ & $32.0 \pm 0.62$ & & & \\
\hline \multirow[t]{2}{*}{ Yamuna River Water } & - & - & $36.5 . \pm 1.68$ & $28.0 \pm 1.70$ & $64.5 \pm 3.17$ & 98.6 & 98.7 \\
\hline & 20 & 20 & $55.7 . \pm 3.64$ & $47.4 . \pm 0.82$ & & & \\
\hline
\end{tabular}

${ }^{\text {a }}$ Spiking with Cr(III) and Cr(VI) solutions traceable to NIST.

${ }^{\mathrm{b}}$ Confidence Interval 95\%.

TABLE V

Comparison of Reported On-Line Methods with Proposed System For Cr(III) Determination

\begin{tabular}{|c|c|c|c|c|c|c|c|c|}
\hline Support & Chelating Agent & Eluent & $\begin{array}{l}\text { PT } \\
\text { (s) }\end{array}$ & $\begin{array}{l}\text { Sample } \\
\text { Volume } \\
\text { (mL) }\end{array}$ & $\begin{array}{l}\text { RSD } \\
(\%)\end{array}$ & $\begin{array}{c}\text { LOD } \\
\left(\mu \mathrm{g} \mathrm{L}^{-1}\right)\end{array}$ & $\mathrm{PF}$ & $\begin{array}{l}\text { Ref. } \\
\text { No. }\end{array}$ \\
\hline $\begin{array}{l}\text { Chitosan-FeC } \\
\text { nanoparticles }\end{array}$ & - & $\mathrm{HCl}$ & 4000 & 100 & 2.5 & 0.0524 & 100 & $(23)$ \\
\hline $\begin{array}{l}\text { Chloromethylated } \\
\text { polystyrene }\end{array}$ & $\begin{array}{l}\text { N,N-bis } \\
\text { (naphthylideneimino) } \\
\text { diethylenetriamine }\end{array}$ & $\mathrm{HCl}$ & 225 & 10 & 2.5 & 0.6 & 74 & $(24)$ \\
\hline Divinyl benzene & $\begin{array}{l}\text { Poly 2-(5-methylisoxazol) } \\
\text { methacrylamide-co-2- } \\
\text { acrylamido-2-methyl-1- } \\
\text { propanesulfonic acid }\end{array}$ & $\mathrm{HNO}_{3}$ & 210 & 5.8 & 2.3 & 0.05 & 48 & (25) \\
\hline MWCNTs & - & $\mathrm{HNO}_{3}$ & 180 & 6 & 1.7 & 1.15 & 22 & $(26)$ \\
\hline $\begin{array}{l}\text { Poly(methacrylic } \\
\text { acid) }\end{array}$ & - & $\mathrm{HNO}_{3}$ & - & 87 & 1.46 & 0.84 & 47.3 & $(27)$ \\
\hline Silica & $\mathrm{Al}_{2} \mathrm{O}_{3} / \mathrm{TiO}_{2}$ & $\mathrm{HCl}$ & - & 20 & 2.4 & 0.66 & 17.6 & (28) \\
\hline Silica gel & Niobium(V) oxide & $\mathrm{HNO}_{3}$ & 120 & 15 & 4.6 & 0.34 & 23 & (29) \\
\hline Silica gel & Zirconium oxide & $\mathrm{HNO}_{3}$ & 225 & 15 & 3.0 & 1.90 & 20.8 & (30) \\
\hline PTFE beads & Iminodiacetic acid & $\mathrm{HNO}_{3}$ & 120 & 10 & 1.2 & 0.11 & 68 & $\begin{array}{c}\text { This } \\
\text { work }\end{array}$ \\
\hline
\end{tabular}

PT: preconcentration time; RSD: relative standard deviation; LOD: limit of detection; PF: preconcentration factor.

Comparison of Proposed Method with Reported On-Line Methods

The analytical performance of the proposed method was compared with on-line methods reported in the literature. The reported method has proven to be better in terms of preconcentration factor, detection limit, reagent consumption, sample throughput and reproducibility. In Tables V and VI a comparison of the method reported with some recent on-line methods for $\mathrm{Cr}$ (III) and $\mathrm{Cr}(\mathrm{VI})$ preconcentration is given.

\section{CONCLUSION}

The hyphenated FI-SPE-FAAS system was successfully applied for the preconcentrative speciation of chromium species. The iminodiacetic acid complex of both $\mathrm{Cr}$ (III) and $\mathrm{Cr}$ (VI) species was retained on a 
TABLE VI

Comparison of Reported On-Line Methods with Proposed System For Cr(VI) Determination

\begin{tabular}{|c|c|c|c|c|c|c|c|c|}
\hline Support & Chelating Agent & Eluent & $\begin{array}{l}\text { PT } \\
(\mathrm{s})\end{array}$ & $\begin{array}{l}\text { Sample } \\
\text { Volume } \\
(\mathrm{mL})\end{array}$ & $\begin{array}{l}\text { RSD } \\
(\%)\end{array}$ & $\begin{array}{l}\mathrm{LOD} \\
\left(\mu \mathrm{g} \mathrm{L}^{-1}\right)\end{array}$ & $\mathrm{PF}$ & $\begin{array}{l}\text { Ref. } \\
\text { No. }\end{array}$ \\
\hline \multirow[t]{2}{*}{$\begin{array}{l}\text { Chloromethylated } \\
\text { polystyrene }\end{array}$} & $\begin{array}{l}\text { N,N-bis } \\
\text { (naphthylideneimino) }\end{array}$ & $\begin{array}{l}\text { Buffer Solution } \\
\text { of } 25 \mathrm{M}\end{array}$ & 225 & 10 & 2.2 & 2.5 & 30 & (24) \\
\hline & diethylenetriamine & $\begin{array}{l}\mathrm{NH}_{4} \mathrm{NO}_{3} \text { and } \\
1.0 \mathrm{M} \mathrm{NH}\end{array}$ & & & & & & \\
\hline Dowex $21 \mathrm{~K}$ & - & $\mathrm{HNO}_{3}$ & 17 & 5.8 & 4 & 0.3 & 30 & (25) \\
\hline Llama Fibres & - & & 750 & 25 & 4.3 & 0.30 & 32 & (31) \\
\hline Poly vinyl imidazole & - & $\mathrm{HNO}_{3}$ & - & 87 & 2.0 & 1.58 & 8.6 & $(27)$ \\
\hline $\begin{array}{l}\text { SBA-15 mesoporous } \\
\text { silica }\end{array}$ & $\begin{array}{l}\text { Aminopropyl- } \\
\text { triethoxysilane }\end{array}$ & $\mathrm{HNO}_{3}$ & 300 & - & 2.1 & 0.2 & 44 & (32) \\
\hline UVM-7 & Amino silane & $\mathrm{NaOH}$ & - & 100 & - & 1.2 & 66.7 & (33) \\
\hline Silica & $\begin{array}{l}\text { [3-(2-aminoethyl- } \\
\text { amino)propyl]trimeth- } \\
\text { oxysilane }\end{array}$ & $\mathrm{HCl}$ & - & 20 & 2.4 & 0.27 & 32.98 & (28) \\
\hline Silica gel & Zirconium phosphate & $\begin{array}{l}0.1 \mathrm{M} \text { tris } \\
\text { (hydroxymethyl) } \\
\text { methylamine } \\
\text { (THAM) }\end{array}$ & 225 & 15 & 2.1 & 2.3 & 24.9 & (30) \\
\hline PTFE beads & Iminodiacetic acid & $\mathrm{HNO}_{3}$ & 120 & 10 & 1.4 & 0.13 & 59 & $\begin{array}{l}\text { This } \\
\text { work }\end{array}$ \\
\hline
\end{tabular}

PT: preconcentration time; RSD: relative standard deviation; LOD: limit of detection; PF: preconcentration factor

mini-column filled with PTFE

beads. The reported system

involves no chemical modification and is based on the physical adsorption of the chromium complex with iminodiacetic acid which further eliminates the step of regeneration since at the end of each cycle the beads are free of the chromium complex. The study on effect of interfering ions revealed that the proposed system shows sufficient tolerance towards the commonly occurring interfering ions. As can be seen in Tables V and VI, the method reported has proven to be better than other reported methods in terms of preconcentration factor, sample consumption, sensitivity, and reproducibility. The method validation was performed by analyzing NIST SRM 1640a Trace Elements in Natural Water.

\section{ACKNOWLEDGMENTS}

The authors are thankful to the University Grants Commission (UGC), New Delhi, India, and the Department of Science and Technology (DST), India, for financial support.

Received August 26, 2017.

\section{REFERENCES}

1. K. Pyrzynska, Trends Anal. Chem. 32, 100 (2012).

2. Guidelines for drinking-water quality, 4th ed., World Health Organization, Geneva, Switzerland (2011).

3. J. Namiésnik, A. Rabajczyk, Crit Rev Environ Sci Tech. 42, 327 (2012)
4. R. Rakhunde, L. Deshpande and H.D. Juneja, Crit. Rev. Environ. Sci. Technol. 42, 776 (2012).

5. D. Kara, Anal Lett. 44, 457, (2011).

6. P. A. Aranda, E. Perino, F. A. Bertolino, J. Raba and I. E de Vito, Microchim. Acta 179, 235 (2012).

7. Z. Fang, Flow Injection Atomic Absorption Spectrometry, John Wiley \& Sons Ltd., West Sussex, England (1995).

8. S. Tiwari, N. Sharma and R. Saxena, International Journal of Advanced Technology in Engineering and Science 3(1), 692 (2015)

9. R. Saxena, S. Tiwari and N. Sharma, RSC Adv. 5, 69196 (2015).

10. D. Das and M. Dutta, Desalin. Water Treat., 51(34-36), 6882 (2013).

11. F. L. Ren, J. Dai and C. Y. Tao, Int. J. Environ. Res. Public Health 9, 1757 (2012). 
12. A. Moghimi, Afr. J. Pure Appl. Chem. 7(4), 146 (2013).

13. R. Saxena, P. L. Meena and S. Tiwari, Instrum. Sci. Technol.. 44(2), 210 (2016).

14. R. Saxena, N. Sharma and S Tiwari, Anal. Sci. 31, 1303 (2015).

15. S. Tiwari, N. Sharma and R. Saxena, New J. Chem. 40, 1412 (2016).

16. A. N. Anthemidis, G. A. Zachariadis and J. A. Stratis, Talanta 54, 935 (2001).

17. Z. H. Wang, Z. P. Zhang, Z. P. Wang, L. W. Liu and X. P. Yan, Anal Chim Acta 514, 151 (2004).

18. S. Hirata, K. Honda, O. Shikino, N. Maekawa and M. Aihara, Spectrochimica Acta Part B, 55 , 1089 (2000).

19. R.K. Misra, S.K. Jain, P.K. Khatri, J. Hazard. Mater. 85, 1508 (2011).

20. S. Tiwari, N. Sharma and R. Saxena, Anal Sci. 32, 1321 (2016).

21. N. Sharma, S. Tiwari and R. Saxena, RSC Adv. 6, 10775 (2016).

22. J. Wang, X. Ma, G. Fang, M. Pan, X. Ye and S. Wang, J. Hazard. Mater. 186, 1985 (2011).

23. Y. Wu, Y. Jiang, D. Han, F. Wang and J. Zhu, Microchim. Acta,159, 333 (2007).

24. M. A. Chamjangali, N. Goudarzi, M. Mirheidari and B. Bahramian, J. Hazard. Mater. 192, 813 (2011).

25. Ş. Saçmacı, S. Şahan, Ş. Kartal, M. Saçmac1, U. Şahin and A. Ülgen, Talanta 120, 391 (2014).

26. H. Yu, W. Sun, X. Zhu, X. Zhu and J. Wei, Anal. Sci. 28, 1219 (2012).

27. M. Z. Corazza, E. S. Ribeiro, M. G. Segatelli and C. R. T. Tarley, Microchem. J. 117, 18 (2014).

28. C. R. T. Tarley, G. F. Lima, D. R. Nascimento, A. R. S. Assis, E. S. Ribeiro, K. M. Diniz, M. A. Bezerra and M. G. Segatelli, Talanta 100, 71 (2012).

29. E. Carasek, E. Martendal and H. F. Maltez, J. Hazard. Mater.,161, 450 (2009).

30. E. Carasek and H. F. Maltez, Talanta 65, 537 (2005).

31. P. R. Monasterio, J. C. Altamirano, L. D. Martínez and R. G. Wuilloud,
Talanta 77, 1290 (2009).

32. Z. Wanga, D. M. Fanga, Q. Li, L. X. Zhang, R. Qiana, Y. Zhua, H. Y. Qua and Y. P. Dub, Anal. Chim. Acta 725, 81 (2012).

33. H. Shirkhanloo, A. Khaligh, F. Golbabaei, Z. Sadeghi, A. Vahid and A. Rashidi, J. Environ. Health Sci. Eng. 13(47), 1 (2015). 